\title{
AN ANALYSIS OF THE INFLUENCE OF THE CONSPICUOUS CONSUMPTION OF FAST FASHION ON IDENTITY CONSTRUCTION ON INSTAGRAM
}

\author{
BRUNA L. L. DANTAS ${ }^{1}$ \\ http://orcid.org/0000-0002-3935-5947 \\ NELSIO R. ABREU ${ }^{1}$ \\ http://orcid.org/0000-0001-7024-5642
}

To cite this paper: Dantas, B. L. L., \& Abreu, N. R. (2020). An analysis of the influence of the conspicuous consumption of fast fashion on identity construction on Instagram. Revista de Administração Mackenzie, 21 (5), 1-28. doi:10.1590/1678-6971/eRAMG200043

Submission: Apr. 8, 2019. Acceptance: May 26, 2020.

Federal University of Paraíba (UFPB), João Pessoa, PB, Brazil.

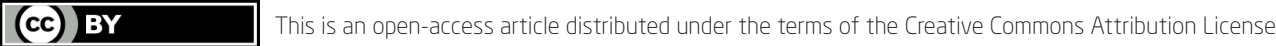

\footnotetext{
This paper may be copied, distributed, displayed, transmitted or adapted if provided, in a clear and explicit way, the name of the journal, the edition, the year and the pages on which the paper was originally published, but not suggesting that RAM endorses paper reuse. This licensing term should be made explicit in cases of reuse or distribution to third parties. It is not allowed the use for commercial purposes.

Este artigo pode ser copiado, distribuído, exibido, transmitido ou adaptado desde que citados, de forma clara e explícita, o nome da revista, a edição, o ano e as páginas nas quais o artigo foi publicado originalmente, mas sem sugerir que a RAM endosse a reutilização do artigo. Esse termo de licenciamento deve ser explicitado para os casos de reutilização ou distribuição para terceiros. Não é permitido o uso para fins comerciais.
} 


\section{ABSTRACT}

Purpose: The objective of this investigation is to analyze the influence of the conspicuous consumption of fast fashion products on Instagram on the identity construction process of female fashion consumers.

Originality/value: Filling a gap in the literature relating to conspicuous consumption and identity construction, this investigation analyzes the consumption dynamics, investigating relevant phenomena on a current and relevant online social network: Instagram; and explaining, in an analysis by categories, the continued dissatisfaction of consumers with the goods that drive and determine the dynamics of fast fashion consumption.

Design/methodology/approach: The methodology was qualitative, triangulating data from participant observation, interviews, and online focus groups. Eleven women were interviewed, and three focus group sessions were conducted, with a total of sixteen participants. The data were analyzed through content analysis with categories before and subcategories that emerged afterwards.

Findings: The findings show the conspicuous consumption of fast fashion products on Instagram as creators of sense, self-concept, and self-image, following and demonstrating the lifestyle of consumers. The satisfaction resulting from people's approval, the goods used for compliance in social groups, and the continued dissatisfaction with their possession are observed, which drives fast fashion consumption. The constructed identities are presented as contextual, fluid, and fragmented.

\section{KEYWORDS}

Conspicuous consumption. Identity construction. Fast fashion. Online social network. Instagram. 


\section{INTRODUCTION}

In light of the sociocultural revolution taking place in postmodern society, changes must be made to the study of marketing and consumer behavior, particularly with regard to tracking cultural changes in the way subjects consume (Thoumrungroje, 2014). Understanding consumption as a social practice with many different meanings, it is important to study a range of factors within individuals and communities to understand in greater detail the motivations involved in this practice (Barbosa \& Campbell, 2006).

Setting motivations for consumption to the side and moving beyond economic issues, one finds conspicuous consumption, or ostentatious consumption, postulated as the consumption of goods aimed at attaining status in society as a whole or within a specific group (Mason, 1984; Veblen, 1988; McCracken, 2003; Belk, 2013). Online social networks provide an environment that is conducive to the spread of conspicuous consumption behavior.

The power online social networks have over social interactions, and consumption behavior is surely remarkable (Barasch, Zauberman, \& Diehl, 2018). Instagram is a space conducive to publication through posts that every user can make on their account. Users often post photos of their clothing, demonstrating concern with the image they are trying to convey.

Interactions between users also have an influence on consumption behavior. From this perspective, certain elements need to be investigated in more detail, as they are not easy to identify, such as the relationships among the people using online social networks; these people not only transmit information but contribute to the construction and interpretation of common ideals (Nowak \& Vallacher, 2005). Interpersonal interactions carry meanings capable of molding and constituting identities, thus, enabling the construction of a personal image, as well as other forms of identity (Shankar, Elliot, \& Fitchett, 2009).

An understanding of identity construction is a central element in studies of consumer behavior (Arnould \& Thompson, 2005). Within a range of studies on identity, this study was mainly based on the studies by Hall (2006) and Carrieri, Paula, and Davel (2008), adopting the concepts of contextual identity and fluid and fragmented identity adopted in the context of postmodernity so represented by the dynamics expressed in the online environment.

Therefore, consumers naturally need recognition of their identities. On the other hand, many of the brands, the science and the marketing practice are searching for theories and models that analyze and capture the identity 
dynamics present in the consumer relations (Kipnis, Demangeot, Pullig, \& Broderick, 2019).

Understanding consumers' stance toward consumption, based on their behavior, makes it possible to substantiate theoretical discussions about this phenomenon, particularly with regard to changes that have occurred with the advent of online consumption (Palmero, Rodríguez, \& Torres, 2016). These considerations give rise to the central inquiry of this article, which seeks to answer the following question:

- How does the consumption of fast fashion on Instagram affect the identity construction process of women?

Therefore, the objective of this investigation is to analyze the influence of the conspicuous consumption of fast fashion products on Instagram on the identity construction process of female fashion consumers.

In order to meet the proposed objective, we performed a qualitative methodology, which used triangulation with techniques of participant observation, interview, and online focus group. The data were analyzed through content analysis. This article continues below with a literature review, a description of the methodological procedures, a discussion on the results, and final considerations.

\section{CONSUMPTION AND IDENTITY CONSTRUCTIONS}

\subsection{Conspicuous consumption and fast fashion}

The analysis of non-economic or non-utilitarian demand has been seen by some authors. The first propositions concerning conspicuous consumption were postulated by Thorstein Veblen. The author proposed that conspicuous consumers sought to impress people with their possessions in order to increase their standing in society, and, consequently, maintain or improve their social status. For him, the demand for goods and services arises from the need to establish social networks and the desire for pecuniary emulation (Veblen, 1988). Agreeing with the author, Douglas \& Isherwood (2002) propose consumer decisions are a vital source of the culture of the moment, and things whose possession means wealth are not needed by themselves, but by the social relations they sustain.

In addition to satisfying basic needs, conspicuous consumption - a symbol of status - also contributes to establishing social relations and to the 
structure of social organization (Patsiaouras \& Fitchett, 2012). Thus, Veblen's (1988) claim that the demand for goods and services arises from the need to establish social networks, as well as from the aspiration towards social emulation confirm this statement. Furthermore, goods carry social and cultural values and serve as communicators. They carry social meanings relevant to demonstrating the class to which the individual belongs and are responsible for establishing social relations (Douglas \& Isherwood, 2002). Chaudhuri and Majumdar (2006, p. 5) propose as constituents of conspicuous consumption: 1 . the ostentation and signaling; 2 . the singularity; and 3 . the social conformity.

Previous studies show that the conspicuous consumption can play important signaling roles in relationships, women can use it to draw attention from potential rivals (Wang \& Griskevicius, 2014), and consumers post photos to intentionally be seen consuming products of determined brands, and thus, impress others and gain social approval (Ferraro, Kirmani, \& Matherly, 2013). Studies like Taylor's (2016) conclude that social networks, such as Facebook, emphasize the characteristics of the conspicuous consumption behavior due to the need for prestige, status, and acceptance of users by informing possessions or experiences that may or may not be true. The conception of this world, possibly dematerialized by online consumers, entails the creation of a version of themselves.

Individuals' consumption of goods, therefore, may represent an extension of their personal identity, which the author Belk (1988) calls "extended self": a good becomes a part of the self when its acquisition is based on the self. Through the acquisition of goods and their appropriation, online consumption contributes to the construction of the "extended self".

Besides serving to social status perceptions, the motivations for this type of consumption seem to be related to cultural factors (McCraken 1986; Vohra 2016), globalization, reference groups, demographic factors (Vohra, 2016), ethnicity, social class (Ryabov, 2016), public self-awareness, materialism, self-esteem and fashion (Veblen, 1988).

In this sense, from the consumption of fashion, social groups legitimize their spaces in society and use fashion to build the identity of the subjects (Belk, 2013).

Fashion, as a concept, was first studied in the late Middle Ages and early Renaissance, following the development of cities and the emergence of distinct social classes, in a period when consumer concepts began to change and preferences switched from durable products to fashion goods, which carried meanings capable of communicating an individual's values to society, making them equal to the nobility (Lipovetsky, 2007; McCracken 2007). 
In terms of the fashion industry's business models, divided by Pinheiro, Oliveira, Steinhaus, and Cherutti (2017) into traditional and innovative, traditional businesses involve a number of stages, such as creation, fashion consulting, manufacturing, textiles, fashion journalism, maisons (luxury products), fashion marketing, patternmaking, fashion production, retail, and window dressing. Innovative businesses, which are the focus of the present study, involve branding advice, fashion blogs, customization, eco-fashion, e-commerce and fast fashion. However, one cannot ignore the social and environmental implications that this kind of industry can generate (Cordeiro, Batista, Silva, \& Pereira, 2013; Li et al., 2014; Nunes \& Silveira, 2016; Hill \& Lee, 2015; Park \& Kim, 2016).

The commercialization and consumption of these products take place significantly in the online environment. Studies show that the audience produced by bloggers produces a "mega-phone effect" capable of generating significant market returns, especially in the fashion context, for the small portion that achieves enough engagement (McQuarrie, Miller, \& Phillips, 2012).

Regardless of why people wear fashion, it is worth noting that it represents a way in which social space is known, explored, communicated and reflected, and represents a means by which people express themselves and their identities (Lipovetsky, 2007).

\subsection{Identity construction}

The studies on identity bring a multiplicity of concepts regarding their constructions. In a theoretical essay, Carrieri et al. (2008) compile a series of prisms through which identity can be analyzed and point out that they can be multiple, fluid or autonomous. The concept of identity can acquire different meanings in different fields of study.

In the field of psychology, which treats identity as a quilt composed of the experiences lived by individuals, it is believed that there is autonomy regarding identity constructions, that is, they do not depend on the social actors, but on the subject himself/herself. On the other hand, sociology treats identity as a result of interactions composed by relationships and positioning between subjects. Still, identity is treated as something built in microprocesses, within a perspective in which there is no solidity in organizations and relationships, and it is up to the subjects to locate and selfdefine themselves as parts of the social environment (Carrieri et al., 2008).

In the social sciences, identity is conceptualized by Erikson (1987) as a uniform and continuous subjective feeling that intimately defines what 
a person is. For Backes (2012, p. 30) a "sense of identity is formed by the integration of self-images, and the ego is the internal agency responsible for the continuous representation of the self, selecting and making meaningful identifications". As Procházka (2018) points out, subjects textualize themselves in an online environment and perform identity practices carefully managed to project a self according to their choice.

With regard to identity, the perspectives of social science studies have changed considerably. Within the postmodern perspective, identity is no longer considered a unified, fixed or stable construction; on the contrary, it is dynamic and must be assembled and reassembled, produced and reproduced. In this sense, identity is no longer considered a 'thing' but has become a process or project (Shankar et al., 2009).

Contextual identity, according to Hall (2006, p. 38), concerns identity construction that is

[...] not fixed, but poised, in transition between different positions; which draw [s] on different cultural traditions at the same time; and which [is] the product of those complicated cross-overs and cultural mixes which are increasingly common in a globalized world.

Thus, identity is something formed over time through unconscious processes rather than something innate that existed in consciousness at the moment of birth (Hall, 2006).

Besides the individual conception and self-concept, identities are socially formed, as they depend on the recognition and legitimation of others who are part of the social reality of the subject; therefore, identity can be considered relational and comparative. Still, the identity construction is a continuous process, subject to change, reconstruction, and fragmentation (Carrieri et al., 2008).

The concept of identity is a project by individuals that develops continuously, based on an attempt to create a rational self, even though this self is fragmented and diversified, and based on other constructs (Shankar et al., 2009). Culture is a space for the production and circulation of identity representations. Within this perspective, the consumer market is considered to be the "source of symbolic resources through which people construct their identity narratives" (Zanette, Lourenço, \& Brito, 2013, p. 540). The act of consuming becomes one of the most important human activities, not only for the economy but also for the creation of meaning by individuals, their recognition, and the construction of their identity and culture. From this assump- 
tion, it can be understood that the creation of meaning through consumption permeates cultural elements (Trindade, Ayrosa, \& Sauerbronn, 2015).

Goods play a fundamental role in the legitimization and recognition of an individual's identity based on their possessions (Belk, 1988). In his studies on identity, Belk (1988) analyzed the ways in which possessions or symbols, goods, and places become part of what individuals are and how they perceive their own "extended self" and, consequently, their identity. Culture, consumption and social relations are considered engines for individuals' identity construction, as it is through social interactions that the consumer displays objects of consumption, in an extension of the self (Belk, 1988), in order to affirm an identity project that is subject to other people's judgment (Zanette et al., 2013).

Thus, it is understood that identity involves a sense of belonging, of affiliation of a subject with his/her group (Vasconcelos \& Vasconcelos, 2001). Carrieri et al. (2008, p. 132) add that the individual while having a self-recognition for his/her similarities with himself/herself, recognizes his/ her self by his/her differences from others; thus, this act of comparison results in the "identity of a dialectical process of identification and differentiation expressed, above all, in social relations".

\section{METHODOLOGY}

The research approach is qualitative, as it is an analysis of behaviors (Godoy, 1995; Creswell, 1998, Merriam, 2009). Qualitative research is described as inductive, constructivist and interpretive. In the case of this study, its epistemological position is interpretive, seeking to understand the social world by interpreting the world and its social actors. Epistemologically, qualitative research is constructivist, i. e., social properties result from interactions between the actors rather than being an isolated phenomenon (Bell \& Bryman, 2018).

To achieve the proposed objective, triangulation was used, in order to maximize data reliability through methodological integration (Duarte, 2009). Intermethod triangulation, described by Denzin and Lincoln (2008) as using different methods in relation to the same object of study, was used. This use is justified by believing that, although it is not possible to generalize, one can compare the results obtained in an attempt to analyze the convergence of the results and thus consider them more reliable (Flick, 2009).

The data were collected through participant observation, one online and ten face-to-face interviews conducted by the researcher, and three online 
focus group sessions were also held using a semi-structured script that was developed based on the theory studied. The corpus size was of 11 participants of interviews and 16 participants of online focus groups.

The participants were selected through analyses performed during participant observation. As the study focused on fast fashion consumers, women whose profiles contained preferably images showing the use of these products were invited to participate in the interviews and online focus groups. The study was restricted to women because they were observed to be more involved in the consumption of fast fashion on Instagram than men.

We opted for the online research environment, and restricted the investigation to the social network Instagram. However, we emphasize that ethical aspects were taken into consideration, as pointed out by Elovici, Fire, Herzberg and Shulman (2014), such as the consent of the participants, which was obtained through the Informed Consent Form (ICF), no personal information was disclosed or directly or indirectly exposed without context, as well as informing all the participants of the average length of time spent in each focus group and interview, and the discussion does not present individual weaknesses, but findings from the statements regarding the influence of consumption on the conspicuous perspective in the virtual environment.

Regarding the choice of Instagram, it was because it is an application developed for mobile devices, such as tablets and smartphones, and which can also be accessed on a computer, for free, its foundation was in 2010 (Smith, 2017) and it is widely used in Brazil, with about 66 million users, a significant number, which puts it in the ranking as the second country which has more profiles in the application (Agrela, 2019).

The interview phase began on October 28, 2017 and ended on November 24,2017 . The interviews were conducted in person, with the exception of one that was conducted via video call on the WhatsApp application. The interviews were carried out until enough relevant information had been obtained for the data analysis phase, based on the concept of saturation proposed by Glaser and Strauss (1967). Regarding the online focus group, they were worthy of 16 women by telephone and met three attempts to get them together in each session.

In the following phase, the one of data collection through the online focus group, we selected seven women for the first session, six for the second and three for the third phase. Below, the figures 3.2, 3.3, and 3.4 present the profile of the participants. The notes for the group participants were assigned according to the figures and in parentheses the focus group they participated in. 


\section{(Figure 3.1)}

INDIVIDUAL INTERVIEWS

\begin{tabular}{clllllc}
\hline Name & \multicolumn{1}{c}{ Schooling } & Profession & Age & City-State & Followers & Following \\
\hline 11 & Graduated & Lawyer & 26 & Mossoro-RN & 761 & 1,575 \\
\hline 12 & Incomplete higher education & Actress & 24 & Mossoro-RN & 1158 & 798 \\
\hline 13 & High school & Student & 16 & Mossoro-RN & 1160 & 1,538 \\
\hline 14 & Incomplete higher education & Student & 19 & Mossoro-RN & 1758 & 1,006 \\
\hline 15 & Master's degree & Teacher & 34 & Joao Pessoa-PB & 1116 & 875 \\
\hline 16 & Incomplete higher education & Student & 25 & Caico-RN & 1007 & 933 \\
\hline 17 & Master's degree & Teacher & 26 & Mossoro-RN & 1430 & 927 \\
\hline 18 & Incomplete higher education & Student & 20 & Caico-RN & 1156 & 1,145 \\
\hline 19 & Incomplete higher education & Student & 21 & Angicos-RN & 2091 & 1,184 \\
\hline 110 & Incomplete higher education & Student & 19 & Angicos-RN & 1428 & 1,124 \\
\hline 111 & Incomplete higher education & Student & 23 & Campo Redondo-RN & 3137 & 1,091 \\
\hline
\end{tabular}

Note: E1: interview 1; E2: interview 2; E3: interview 3; E4: interview 4; E5: interview 5; E6: interview 6; E7: interview 7; E8: interview 8; E9: interview 9; E10: interview 10; E11: interview 11.

Source: Elaborated by the authors.

\section{(Figure 3.2) \\ FOCUS GROUP 1}

\begin{tabular}{lllllcc}
\hline Name & \multicolumn{1}{c}{ Schooling } & Profession & Age & City-State & Followers & Following \\
\hline P1(FG1) & Graduated & Nurse & 24 & Natal-RN & 810 & 835 \\
\hline P2(FG1) & Incomplete higher education & Student & 23 & Mossoro-RN & 963 & 756 \\
\hline P3(FG1) & Graduated & Nurse & 26 & Rio de Janeiro-RJ & 1,738 & 913 \\
\hline P4(FG1) & Incomplete higher education & Social media & 22 & Mossoro-RN & 2,810 & 2,482 \\
\hline P5(FG1) & Incomplete higher education & Student & 23 & Mossoro-RN & 406 & 240 \\
\hline P6(FG1) & Incomplete higher education & Student & 27 & Mossoro-RN & 1,417 & 1,315 \\
\hline P7(FG1) & Master's degree & Agronomist & 27 & Mossoro-RN & 1,507 & 864 \\
\hline
\end{tabular}

Nota: PI(FG1): participant 1 of focus group 1; PG2(FGI): participant 2 of focus group 1; P3(FG1): participant 3 of focus group 1; P4(FG1): participant 4 of focus group 1; P5(FG1): participant 5 of focus group 1; P6(FG1): participant 6 of focus group 1; P7(FG1): participant 7 of focus group 1 . 


\section{(Figure 3.3)}

FOCUS GROUP 2

\begin{tabular}{lllllcc}
\hline Name & \multicolumn{1}{c}{ Schooling } & Profession & Age & City - State & Followers & Following \\
\hline P1(FG2) & Graduated & Publicist & 24 & Brasilia-DF & 1,723 & 642 \\
\hline P2(FG2) & Graduated & Student & 27 & Campina Grande-PB & 1,889 & 1,893 \\
\hline P3(FG2) & Incomplete higher education & Student & 22 & Mossoro-RN & 2,018 & 822 \\
\hline P4(FG2) & Incomplete higher education & Student & 16 & Mossoro-RN & 1,425 & 873 \\
\hline P5(FG2) & Master's degree & Teacher & 25 & Mossoro-RN & 1,091 & 872 \\
\hline P6(FG2) & Incomplete higher education & Student & 24 & Mossoro-RN & 2,993 & 2,943 \\
\hline
\end{tabular}

Nota: PI(FG2): participant 1 of focus group 2; P2(FG2): participant 2 of focus group 2; P3(FG2): participant 3 of focus group 2; P4(FG2): participant 4 of focus group 2; P5(FG2): participant 5 of focus group 2; P6(FGZ): participant 6 of focus group 2 .

Source: Elaborated by the authors.

\section{(Figure 3.4)}

FOCUS GROUP 3

\begin{tabular}{cllcccc}
\hline Name & \multicolumn{1}{c}{ Schooling } & Profession & Age & City-State & Followers & Following \\
P1(FG3) & Graduated & Makeup artist & 22 & Mossoro-RN & 890 & 1,160 \\
\hline P2(FG3) & Incomplete higher education & Student & 25 & Caico-RN & 1,909 & 2,292 \\
\hline P3(FG3) & Incomplete higher education & Student & 19 & Natal-RN & 2,715 & 1,764 \\
\hline
\end{tabular}

Note: P1(FG3): participant 1 of focus group 3; P2(FG3): participant 2 of focus group 3; P3(FG3): participant 3 of focus group 3.

Source: Elaborated by the authors.

Participant observation was carried out from May to December 2017, having a duration of seven months. The process involved analyzing Instagram posts, found by searching the hashtags "look of the day" and "fast fashion". Using convenience sampling, potential profiles were identified, and their posts were monitored. The findings were recorded in a field diary, observing the connections between the posts and the research theme. This type of observation enables an understanding of the meanings present in the context studied through the perspective of the subjects (Rocha \& Rocha, 2013).

With regard to online focus groups, this technique was considered suitable because the research topic is directly related to the use of the Internet, and thus, the focus groups could be held in an environment that was 
familiar to the participants: in this case, the WhatsApp application. One advantage of online focus groups is that, in general, people may feel less inhibited about expressing their sincere opinions (Abreu, Baldanza, \& Gondim, 2009).

Continuing with the data collection, individual semi-structured interviews were conducted using an interview script that was developed based on the literature review in the present study. The same script was used as a discussion guide for the online focus groups, in order to verify differences in behavior individually and in groups through the participants' answers.

The first focus group session took place on December 1, 2017, with seven participants, as well as the researcher and the advisor, who played the role of group mediators. It lasted one hour and 40 minutes; the second focus group session took place on December 5, 2017, with six participants and the researcher and lasted one hour and 46 minutes; the third online focus group session took place on December 18, 2017, after some rescheduling, based on the participants' availability; the session included three participants, as well as the researcher.

The data were analyzed using the content analysis technique, in which research is used to describe and interpret content found in different types of materials, through the interpretative paradigm (Bardin, 2012). After the data were collected, it was systematically cleaned and separated into the categories provided by the instrument, in addition to the subcategories that emerged from the field.

The categories were previously created based on the theory used and the proposed objective. For this, we developed the data collection instrument from the categories: Consumption in the construction of identity, Conspicuous consumption and Consumption of fast fashion products, each of the categories was based on their respective authors. The floating reading was initially performed, so that subcategories of analysis were defined from the categories already elaborated with the theory; they are explained in the figure below. Following the proposal of Flick (2009), initially, the synthesis of the content analysis was performed, highlighting the main parts of the speeches that could meet the research objective and omitted, condensed and summarized phrases that do not directly meet the goal.

The interpretation of the data took into account the origins of the material collected, the transcription of the data, the meaning details of the speeches (coding unit) and the contexts (contextual unit) in which the focus groups were applied, and then the groups were questioned about what the data means. 
Then, the explanatory analysis of the content was performed, as opposed to the synthesis, clarifying the meanings that were not explicit in the speech. Participant observation data were important at this stage, as it provided broader explanations of the context.

The third step, the structured content analysis, sought to fit the main data into a formal material structure, namely, the content categories elaborated based on the contextualization of the data with the theory and the subcategories that emerged from the field. The data were then evaluated, coded and divided according to the analysis elements elaborated following the same logic of the subcategories. This division is shown in the Figure 3.5.

\section{(Figure 3.5)}

\section{CATEGORIES, SUBCATEGORIES, AND ELEMENTS TO OBSERVE}

\begin{tabular}{|c|c|c|}
\hline Categories & Subcategories & Elements to observe \\
\hline \multirow{9}{*}{$\begin{array}{l}\text { Consumption } \\
\text { in identity } \\
\text { construction }\end{array}$} & \multirow{3}{*}{$\begin{array}{l}\text { Self-concept or } \\
\text { self-image }\end{array}$} & Desire to build an image \\
\hline & & Identity representation through clothes \\
\hline & & Expression of identity through photos on Instagram \\
\hline & \multirow{3}{*}{$\begin{array}{l}\text { Online contemporary } \\
\text { context/visibility and } \\
\text { fragmentation }\end{array}$} & Importance of people's perception \\
\hline & & Influence by people on Instagram \\
\hline & & Desire to be admired by people on social networks \\
\hline & \multirow{3}{*}{ Lifestyle } & Desire to follow desired lifestyle profiles \\
\hline & & Own style expressed by the clothes \\
\hline & & Lifestyle following the consumption \\
\hline \multirow{8}{*}{$\begin{array}{l}\text { Conspicuous } \\
\text { consumption }\end{array}$} & \multirow{3}{*}{$\begin{array}{l}\text { Ostentation and } \\
\text { signaling }\end{array}$} & $\begin{array}{l}\text { Strive to make good photos that show even indirectly the } \\
\text { assets owned }\end{array}$ \\
\hline & & Willingness to impress people with acquired goods \\
\hline & & Concern about the image conveyed through posts \\
\hline & \multirow{3}{*}{$\begin{array}{l}\text { Need for people's } \\
\text { approval }\end{array}$} & Perception of judgment based on possessions \\
\hline & & Need to own specific goods to feel accepted \\
\hline & & Dependence on people's approval to feel good feelings \\
\hline & \multirow{2}{*}{$\begin{array}{l}\text { Conformity in social } \\
\text { groups }\end{array}$} & Must own exclusive goods or belong to a higher class \\
\hline & & Affiliate with people who consume similar things \\
\hline
\end{tabular}




\section{(Figure 3.5 (conclusion))}

\section{CATEGORIES, SUBCATEGORIES AND ELEMENTS TO OBSERVE}

\begin{tabular}{|c|c|c|}
\hline Categories & Subcategories & Elements to observe \\
\hline \multirow{5}{*}{$\begin{array}{l}\text { Consumption of } \\
\text { fast fashion }\end{array}$} & \multirow[b]{2}{*}{ Following fashion trends } & Need to keep up with fashion trends \\
\hline & & $\begin{array}{l}\text { Follow digital influencers and feel that you need those } \\
\text { clothes }\end{array}$ \\
\hline & \multirow{3}{*}{$\begin{array}{l}\text { Continued dissatisfaction } \\
\text { with the goods } \\
\text { possessed }\end{array}$} & Desire to always have more clothes \\
\hline & & Belief that your clothes are no longer fashionable \\
\hline & & $\begin{array}{l}\text { Discard or not using clothes after taking pictures and } \\
\text { posting to Instagram }\end{array}$ \\
\hline
\end{tabular}

Source: Elaborated by the authors.

\section{DISCUSSION OF RESULTS}

\subsection{Consumption in identity construction}

The first category, analyzed according to the theory outlined in the present study, relates to consumption in identity construction. Thereby, some subcategories emerged: self-concept or self-image; online contemporary context, visibility and fragmentation, and lifestyle.

When asked about self-concept, how they would like to be perceived by other people on Instagram and if they thought they were perceived the way they would like to be, most participants reported that they had never stopped to think about that, as illustrated by the following statement: "This one is hard to answer LOL. I never thought exactly about the image I wanted to convey, LOL But I didn't want to show too many bad feelings, nor use Instagram as a source of indirect messages" (P5[FG2]).

Exploring the collected data, it was also possible to see that meaning was constructed based on cultural elements - in this case, fashion - as indicated by Castells (1999) and Trindade et al. (2015), as well as on the category of contextual identity, based on Hall (2006), which synthesizes the way identity construction is established based on consumption. In each context, subjects use products and promote behaviors that are consistent with their identity, while avoiding those that are inconsistent (Coleman \& Williams, 2013). 
I usually follow some fashion profiles such as clothing brands and magazines that I like, but most of them are of lifestyles that suit me, travels, gastronomy (P2(FG2).

We are very attracted to what we find in common with others (P1[FG3]).

The participants thought about issues related to image transmission, demonstrating that they did not usually stop to reflect on the image they were transmitting or did not feel comfortable talking about this issue, although they later reported that they were very concerned about the content they post. Baudrillard (1991) argues that fashion products enable the construction of a social identity that is necessarily linked to the socially circulated image, as well as the construction of what people want to show to others.

I worry because it's a picture of mine being exposed. I don't want people to think I'm being vulgar, it's in that sense (I3).

Deep down I think everyone wants to be admired for something, whether it's dressing well, having good taste (P2[FG2]).

It is clear that there is an overabundance of vanity and concern for image on Instagram. The very tools available within the application facilitate an appreciation of the beautiful and ephemeral, as well as what is being used and posted. Pontes (2013) explains that the concepts of fashion, image and identity are closely linked to the extent that transformations occur simultaneously in society, in fashion and identity representations.

It's weird when the clothes a person wears don't match their personality.

I do not mean that we should judge the person by the "cover", I do not agree with that. However, I believe our clothes can convey a message. And many people make interpretations from what they see (P2[FG3]).

Using the other responses, it was possible to identify representative elements, such as the need to be up-to-date with fashion trends, to have an awareness that one is being judged based on the clothes one is wearing and to worry about being accepted by social groups based on representations of consumption. Fashion goes through countless recontextualizations, especially in the online environment, where they are shared and have a reiterative spread, as Procházka (2018, p. 8) says, "all permutation is based on recognizability and, thus, to some extent on normativity". While people 
have social identities capable of adapting to contexts, they are concerned about judgment and affiliation.

I buy clothes already thinking about many people. Wondering if my friends will like that outfit, if it is my style or theirs (I3).

Not to impress, but at least to show a good image. Generally, to feel "included" (P3[FG2]).

Fashion has, since its inception, according to McCracken (2003), been responsible for reshaping itself as an expression of new identities and lifestyles (Pontes, 2013), as traditional identities lost strength following the process of globalization. If culture and identity were once limited to geographic territories, globalization and the advent of the Internet have allowed them to gain new meanings, grounded in information and consumption.

The participants were also asked about the representation of their own style, through clothing. Some women participating in the study believed that they have a unique lifestyle, which on certain occasions is evident in the clothes they wear. While others believe they do not have their own style, but a number of styles that they match and use when they think it is necessary. Normally worried about not hurting their personal values through the clothes they wear, Giddens (2002) explains that the expression of identities permeates the way people constitute their lifestyles using fashion.

I dress according to the moment I'm living now (P4[FG1).

Yees, because I am a Christian and I don't want people to see me in clothes that are not appropriate! (P4[FG2]).

I am very eclectic! I like to be well dressed but I don't have a unique style. I wear from super high heels to sneakers. Depends on the occasion. However, I am also a Christian and I seek to be "fashion" in a decent way (P2[FG2]).

From a perspective of interactive identity, "the subject still has an inner core or essence that is 'the real me', but this is formed and modified in a continuous dialogue with the cultural words 'outside' and the identities which they offer" (Hall, 2006, p. 11). According to this sociological view, identity fills the gap between the personal, inner world, and the public, outer world, 'stitching' the subject to the structure and aligning their subjective feelings with the objective places they occupy in the social world.

You check my Instagram and that's so me, that is me (I3).

I think it represents a lot of what I am, I always try to convey a little of my humor through the looks and I think I can (P1[FG2]). 
In this conformity environment, the participants co-create, share, assess or interact in any other way with the content and, in doing so, "help to establish and maintain an infinity of lifestyles and identities that other people can sign or contest in a given situation" (Procházka, 2018, p. 1). From this point on, it is possible to observe and discuss contextual identity. For Hall (2006, p. 12), "the subject, previously experienced as having a unified and stable identity, is becoming fragmented; composed, not of a single, but of several identities".

The findings suggest that identities are mutable and subject to change, depending on the context. Barbosa and Campbell (2006) and Santos and Cypriano (2014) argue that the multiplicity of choices has made tastes and desires mutable, requiring identities to be reinforced or confirmed. For Santos and Cypriano (2014, p. 11), "the activity of consuming can be considered as a vital and necessary path to self-discovery, while the marketplace itself becomes indispensable to the process of discovering who we are". The participants reported that, at certain moments in their lives, they consumed more clothes in a certain style, while at others, they focused more on comfort: "My style changes from time to time lol a year ago I only wore clothes with cheerful prints, no matter the season I was always colorful. Today I can't stand prints lol but of course we always have the favorite brands" (P3 [FG1]).

The analysis of identity fragmentation allows identities to be analyzed without being tied to time, but focused on contexts in which "individuals would develop countless superficial appearances, would wear identities like wearing clothes. The postmodern age proposes to the subject to create various identifications for the fragmented world" (Carrieri et al., 2008, p. 134). A constant change and attempt of representativeness through the style of the consumed clothes is observed.

\subsection{Conspicuous consumption}

The category of analysis of this study's results is conspicuous consumption. Relating the theory in the literature review to the findings in the field, based on Chaudhuri and Majumdar (2006), some subcategories emerged: ostentation and signaling; satisfaction resulting from people's approval; and conformity in social groups.

When asked how concerned they were with people's opinions about their Instagram posts, the participants said that they are concerned about the image they are transmitting and that they avoid creating controversy and are especially concerned with the judgments that family and co-workers may express about their photos and videos. Most of them mentioned that they 
are less concerned about the image that they transmit to their friends, in the sense of the content of the posts, although they are still concerned with approval, as in the statement below:

I want to show an image of a person who takes care of herself, I'm vain, I've never hidden it. I also like to post things from my day-to-day life, from my professional life, so people don't think I'm empty-headed, because I think this is a problem that women experience, especially vain women, when we care about beauty, people think that we're frivolous, and that isn't true (I5).

Sometimes I think like this: will this photo have many likes? Will it work? There is no problem, if it does not work, I delete it (I11).

Through participant observation, which involved examining posts on the profiles of the interview participants, it was found that the Instagram users were clearly concerned about posting photos in which they look attractive. However, it is worth noting that, on Instagram - unlike other online social networks - users are more concerned with posting photos that show what they are consuming, be it travel, food or clothing. This network is known to encourage ostentatious consumption (Oliveira, Moutinho, Ferreira, \& Ramos, 2015): “There are people who get close to others for their appearance, because they think they have money by the way they present themselves or for what they post on Instagram" (P1[FG2]).

Veblen (1988), in The theory of the leisure class, focused on the society of appearances in the nineteenth century, which - wrapped up in leisure - consumed and displayed goods in order to demarcate its class in the hierarchical pyramid of consumer society. Although it is not possible to discuss and apply exactly the same reality today, it is possible to draw a parallel between the leisure class of the nineteenth century and the generation of digital influencers that has emerged on Instagram in recent years.

It has happened to me several times, I see a look that some blogger has worn and buy the same for me, but it does not look good and I regret it later. But I think it's normal, everyone goes through that (I2).

It influences a lot. Especially when I see some digital influencer using it. Maybe if I'd seen it in the store's rack, I wouldn't have been interested in trying it (P4[FG2]).

Although this study does not specifically address the context of luxury goods, the participants' statements made it possible to observe Instagram as a social network that values the ownership of individual goods (Ferraro 
et al. 2013), which represents accumulation of wealth and conditions the process of people evaluating their value (Santos \& Cypriano, 2014, p. 4). Respondent P2 (FG1) confirms: "I've heard someone saying: 'so-and-so made an Instagram. I don't know why he did it. That poor guy doesn't belong on Instagram'”.

Posts on Instagram, as well as interactions with them, such as likes and comments, drive the consumption of fast fashion products. The participation of the subjects in public networks increases their desire for consumption, according to the sharing and consumption of images on online social networks (Kozinets, Patterson, \& Ashman, 2016). When an Instagram user posts a photo wearing a piece of clothing, they avoid wearing it again in their subsequent posts, because for them it is important to be seen as someone who follows fashion trends and has enough goods to show on Instagram. According to the dynamics of consumption outlined above, until they are able to obtain a social belonging, the consumption of fast fashion is encouraged.

\subsection{Consumption of fast fashion products}

This category of analysis sought to understand the consumption of fast fashion products shown on Instagram from the perspective of the influence (or lack thereof) of interactions on this online social network. From the findings, contextualized with the theory, emerged the subcategories following fashion trends and continued dissatisfaction with the goods possessed.

Instagram is popularly known as the online social network that has the closest relationship with fashion. Because of the way it works, which primarily involves posting photos and videos, applying filters and sharing images, it is widely used as a means of dissemination in this sector.

I really like to look at Instagram because everything there is beautiful, everything, the trends come there first, the stores post there first, the shop owners do talking stories that are going to post photos, it's much further ahead with that matter of fashion nowadays than other social networks (I11).

Although it is not possible to generalize and categorically state that all women who use Instagram are significant consumers of fast fashion, the participants demonstrated that they attributed meanings to the consumption of these goods, in addition to feeling happy when they consumed clothes, posted photos and received compliments. This process, consciously or not, prompts and encourages the consumption of fast fashion products: "Sometimes I try not to see so many fashion profiles because I get crazy to buy, I try 
to avoid it but at the same time I love checking the trends. It's always a dilemma, but in the end I'm always there watching and enjoying" (P5[FG2]).

The desire to be well regarded and accepted in social groups can consequently encourage the consumption of clothing, in addition to other motivations caused by the digital influencers found on this online social network. This leads to reflections on conscious consumption. The fast fashion model has been criticized and questioned by environmentalists, psychologists and sociologists, due to the social and environmental problems that it involves (Cordeiro, 2013; Park \& Kim, 2016; Li et al., 2014; Hill \& Lee, 2015). When questioned about the desire to consume more clothing, all the participants emphatically explained that they are not satisfied with the clothing they have and that they would like to buy more:

Yes, if there's one thing I like, it's buying clothes. And there's a lot of looks I see on Instagram and want to copy, it's too bad I don't have money lol. God, I feel like a new person lol. I love to buy new clothes, that's what I like to buy the most (P2[FG2]).

\section{WISH I HAD MORE MONEY TO BUY MORE CLOTHES WITHOUT FEELING GUILTY (P1[FG1]).}

According to Cietta (2012), the false impression that fast fashion products can be consumed indiscriminately is implicit in the desire to buy more clothing in order to keep up with fashion trends and be seen as someone who is up-to-date, connected and financially able to own fashion goods. According to Santos and Cypriano (2014, p. 7), goods "are therefore not only the tentatively established and temporarily stabilized ways of establishing social signs and meanings but also the materialized and tangible forms of categories of social classification."

The use of fast fashion products on Instagram is directly related to conspicuous consumption; following other accounts is crucial to the platform, and the display of fashion trends is a common behavior. Whether it is for the dynamics of the fast fashion industry, or for the speed with which information is shared on Instagram, the relationship between these two factors is undeniable.

\section{CONCLUSIONS}

The objective of this research was to analyze the influence of conspicuous consumption of fast fashion products on Instagram, in the process of identity construction of women who consume fashion. 
The relationship between conspicuous consumption and social interactions, present on Instagram, results in the need to display and, consequently, impress people with one's possessions. The simple act of identifying the preferences of different people can generate a sense of belonging in social groups, based on the characteristics and lifestyles with which one identifies. These characteristics are expressions of identity construction, resulting from social interactions, processes for identifying and constructing meanings in the online environment, though consumption.

Identities, then, following the parameters observed in postmodernity, are not static or immutable but assume a fluid and fragmented character. They are supported by the consumption of fashion, which accompanies the construction of identity in the sense of expression and language, capable of not only communicating but also producing social relations.

Although it is now broadly popular, Instagram is still seen as a social network where people have an excess of possessions. The research data allowed us to conclude that people using this online social network want their posts to display their daily lives, consumer goods, and travels and demonstrate their purchasing power. To this end, people follow profiles with which they identify themselves and to whom they hope to become more alike; these profiles, most often of digital influencers who have significant purchasing power to consume or who are sponsored by advertisers, depict women who are vain and concerned with aesthetics.

The search for differentiation and uniqueness - both elements of conspicuous consumption - is present in this sense. However, the authenticity with which the profiles are constructed can be questioned because the styles of the bloggers themselves are shaped by the brands that sponsor them.

The consumption of fast fashion products on Instagram interferes with the identity construction process of women and creates contextual meanings and identities - a determinant for social relations - based on demonstrating consumption and acceptance in groups. It is also possible to conclude that the fashion consumption in question is a representation of contextual identities that undergo alterations according to the meanings attributed to them by the circumstances because identities are not constituted individually, but rather require context in order to be molded.

Consumption is, therefore, a determining factor for identity construction. In the context of Instagram, conspicuous consumption reveals this construction, which is influenced by people who have an excess of possessions or at least show themselves as having them. This is not limited to digital influencers, but it also confirms the horizontalization of consumption influences by people in the same social circle who are admired by users. 
The main contribution of this study is in consumer behavior. Before the present study, other studies discussed the theme under different perspectives, such as Ferraro et al. (2013), on conspicuous consumption of brands, Wang and Griskevicius (2014), on conspicuous consumption and rivalry among women, Nunes and Silveira (2016), on motivations for fast fashion consumption, and Procházka (2018), on identity performance on Facebook.

The collected data made it possible to perceive identity construction as something contextual, confirming the theory proposed by Hall (2006), and also fluid and fragmented, as proposed by Carrieri et al. (2008), often expressed through the use of garments that keep pace with the moment being lived by women and what they want to demonstrate at that moment. In this way, it advances in the theoretical construction on conspicuous consumption and identity constructions in the online context, indicating in the category analysis a continuous dissatisfaction with goods, which drives and determines this type of consumption.

This study, based on social identity, understands that identity constructions are formed from the perspectives of consumption, influences from other people and from contexts. It has the limitation of not postulating and delving into different types of identity, such as multiple and autonomous identities. It is also a limitation of this study to focus on Instagram users who are fast fashion consumers. Therefore, it is suggested to study how fashion consumption is related to multiple and autonomous identities from different consumer profiles. It is also suggested to study the propensity of conspicuous consumption of the slow fashion movement that inspires more conscious consumers and also to investigate conspicuous consumption based on practice, not only the behavior of individuals, but taking into account the theory of practice.

\section{ANÁLISE DA INFLUÊNCIA DO CONSUMO CONSPÍCUO DE FAST FASHION NAS CONSTRUÇÕES IDENTITÁRIAS NO INSTAGRAM}

\section{RESUMO}

Objetivo: O objetivo desta investigação é analisar a influência do consumo conspícuo de produtos fast fashion no Instagram, no processo de construção identitária das mulheres consumidoras de moda feminina. 
Originalidade/valor: Com o propósito de preencher a lacuna existente na literatura no que concerne aos estudos que relacionam consumo conspícuo e construções identitárias, esta investigação analisa como se dá a dinâmica de consumo investigando fenômenos relevantes num ambiente atual das redes sociais on-line, o Instagram, e explicando, numa análise por categorias, a insatisfação contínua dos consumidores com os bens que impulsiona e determina a dinâmica de consumo fast fashion.

Design/metodologia/abordagem: A metodologia consistiu numa abordagem qualitativa, em que se utilizou a triangulação dos dados com as técnicas de observação participante, entrevista e grupo focal on-line. Entrevistaram-se 11 mulheres e realizaram-se três sessões de grupo focal, contando no total com 16 participantes. Os dados foram analisados por meio da análise de conteúdo com categorias a priori e subcategorias que surgiram a posteriori.

Resultados: Os resultados encontrados apresentam o consumo conspícuo de produtos fast fashion no Instagram como criadores de sentido, autoconceito e autoimagem, acompanhando e demonstrando o estilo de vida das consumidoras. Observam-se a satisfação resultante da aprovação das pessoas, os bens utilizados para a conformidade em grupos sociais e a contínua insatisfação com a sua posse, o que impulsiona o consumo de fast fashion. As identidades construídas apresentam-se como contextuais, fluidas e fragmentadas.

\section{PALAVRAS-CHAVE}

Consumo conspícuo. Construções identitárias. Fast fashion. Rede social on-line. Instagram.

\section{$\int$ REFERENCES}

Abreu, N. R., Baldanza, R. F., \& Gondim, S. M. G. (2009). Os grupos focais on-line: Das reflexões conceituais à aplicação em ambiente virtual. Journal of Information Systems and Technology Management, 6(1), 5-24.

Agrela, L. (2019). Estes são os dez países que mais usam o Instagram. Retrieved from https://exame.abril.com.br/tecnologia/estes-sao-os-dezpaises-que-mais-usam-o-instagram/ 
Arnould, E. J., \& Thompson, C. J. (2005). Consumer culture theory (CCT): Twenty years of research. Journal of Consumer Research, 31 (4), 868-882.

Barasch, A., Zauberman, G., \& Diehl, K. (2018). How the intention to share can undermine enjoyment: Photo-taking goals and evaluation of experiences. Journal of Consumer Research, 44(6), 1220-1237.

Backes, A. L. (2012). Subjetividade no trabalho e mudança organizacional: Sustentação e reconstrução identitária do funcionário. Revista Administração em Diálogo-RAD, 14(3), 24-53.

Barbosa, L., \& Campbell, C. (2006). Cultura, consumo e identidade. Rio de Janeiro: FGV.

Bardin, L. (2012). Análise de conteúdo. São Paulo: Edições 70.

Baudrillard, J. (1991). Simulacros e simulação. Lisboa: Relógio D’Água.

Belk, R. (1988). Possessions and extended self. Journal of Consumer Research, 15(2), 139-168.

Belk, R. W. (2013). Extended self in a digital world. Journal of Consumer Research, 40(3), 477-500.

Bell, E., Bryman, A., \& Harley, B. (2018). Business research methods. Oxford: Oxford University.

Carrieri, A. D. P., Paula, A. P. P. D., \& Davel, E. (2008). Identity in organizations: Multiple? fluid? autonomous? Organizações \& Sociedade, 15(45), 127-144.

Castells, M. (1999). O poder da identidade. São Paulo: Paz e Terra.

Chaudhuri, H. R., \& Majumdar, S. (2006). Of diamonds and desires: Understanding conspicuous consumption from a contemporary marketing perspective. Academy of Marketing Science Review, (1), 1-18.

Cietta, E. (2012). A revolução do fast-fashion. São Paulo: Estação das Letras e Cores.

Coleman, N. V., \& Williams, P. (2013). Feeling like my self: Emotion profiles and social identity. Journal of Consumer Research, 40(2), 203-222.

Cordeiro, T. A., Batista, M. M., Silva, M. A. P., \& Pereira, G. D. F. (2013). Consumidora consciente?! Paradoxos do discurso do consumo sustentável de moda. Revista Brasileira de Marketing, 12(3), 1-22.

Creswell, J. W. (1998). Qualitative inquiry and research design: Choosing among five traditions. London: Sage.

Denzin, N. K., \& Lincoln, Y. S. (Eds.). (2008). The landscape of qualitative research (3rd ed.). London: Sage. 
Douglas, M., \& Isherwood, B. (2002). The world of goods: Towards an anthropology of consumption. London: Routledge.

Duarte, T. (2009). A possibilidade da investigação a 3: Reflexões sobre triangulação (metodológica). Retrieved from https://repositorio.iscte.pt/handle/ $10071 / 131$

Elovici, Y., Fire, M., Herzberg, A., \& Shulman, H. (2014). Ethical considerations when employing fake identities in online social networks for research. Science and Engineering Ethics, 20(4), 1027-1043.

Erikson, E. H. (1987). Identidade: Juventude e crise (2a ed.). Rio de Janeiro: Guanabara.

Ferraro, R., Kirmani, A., \& Matherly, T. (2013). Look at me! Look at me! Conspicuous brand usage, self-brand connection, and dilution. Journal of Marketing Research, 50(4), 477-488.

Flick, U. (2009). Introdução à pesquisa qualitativa (3a ed.). Porto Alegre: Artmed.

Glaser, B., \& Strauss, A. L. (1967). The Discovery of Grounded Theory. Chicago: Aldine.

Giddens, A. (2002). Modernidade e identidade. Rio de Janeiro: Jorge Zahar.

Godoy, A. S. (1995). Introdução à pesquisa qualitativa e suas possibilidades. RAE-Revista de Administração de Empresas, 35(2), 57-63.

Hall, S. (2006). A identidade cultural na pós-modernidade (11a ed.). (T. T da Silva \& G. L. Louro, Trad.). Rio de Janeiro: DP\&A.

Hill, J., \& Lee, H. (2015). Sustainable brand extensions of fast fashion retailers. Journal of Fashion Marketing and Management, 19(2), 205-222.

Kipnis, E., Demangeot, C., Pullig, C., \& Broderick, A. J. (2019). Consumer multicultural identity affiliation: Reassessing identity segmentation in multicultural markets. Journal of Business Research, 98, 126-141.

Kozinets, R., Patterson, A., \& Ashman, R. (2016). Networks of desire: How technology increases our passion to consume. Journal of Consumer Research, 43(5), 659-682.

Li, Y., Zhao, X., Shi, D., \& Li, X. et al. (2014). Governance of sustainable supply chains in the fast fashion industry. European Management Journal, (32), 823-836.

Lipovetsky, G. (2007). A felicidade paradoxal: Ensaio sobre a sociedade de hiperconsumo. São Paulo: Companhia das Letras.

Mason, R. (1984). Conspicuous consumption: A literature review European. Journal of Marketing Research, 18(3), 26-39. 
McCracken, G. (1986). Clothing as language: An object lesson in the study of the expressive properties of material culture. In B. Reynolds, \& M. A. Stott (Eds.), Material Anthropology: Contemporary approaches to material culture. New York: University Press of America.

Merriam, S. (2009). Qualitative Research: A Guide to Design and Implementation. (3rd rev. ed.) San Francisco: Jossey-Bass.

McCracken, G. (2003). Cultura \& consumo. Rio de Janeiro: Mauad.

McCracken, G. (2007). Cultura e consumo: Uma explicação teórica da estrutura e do movimento do significado cultural dos bens de consumo. Revista de Administração de Empresas, 47(1), 99-115.

McQuarrie, E. F., Miller, J., \& Phillips, B. J. (2012). The megaphone effect: Taste and audience in fashion blogging. Journal of Consumer Research, 40(1), 136-158.

Nowak, A., \& Vallacher, R. R. (2005). Information and influence in the construction of shared reality. IEEE: Intelligent Systems, 1, 90-93.

Nunes, M. P., \& Silveira, G. A. (2016). Análise das motivações do consumidor de fast-fashion. Revista de Administração Imed, 6(1), 56-71.

Oliveira, M. A., Moutinho, R., Ferreira, J. J. P. F., \& Ramos, A. L. (2015). Present and future languages - How innovation has changed us. Journal of Technology Management \& Innovation, 10(1), 166-182.

Palmero, R. J., Rodríguez, S. J., \& Torres, T. J. M. (2016). Utilización de internet y dependencia a teléfonos móviles en adolescentes. Revista Latinoamericana de Ciencias Sociales, Niñez y Juventud, 14(2), 1357-1369.

Park, H., \& Kim, Y. K. (2016). An empirical test of the triple bottom line of customer-centric sustainability: The case of fast fashion. Fashion and Textiles, 3(25), 1-18.

Patsiaouras, G., \& Fitchett, J. A. (2012). The evolution of conspicuous consumption. Journal of Historical Research in Marketing, 4(1), 154-176.

Pinheiro, C. M. P., de Oliveira, C. B., Steinhaus, C., \& Cherutti, M. (2017). Modelos de negócios na área da Moda: Um estudo sobre setores tradicionais e inovadores. ModaPalavra e-periódico, 10(20), 3-22.

Pontes, M. H. (2013). Moda, imagem e identidade. Achiote.com: Revista Eletrônica de Moda, 1 (1), 1-15.

Procházka, O. (2018). A chronotopic approach to identity performance in a Facebook meme page. Discourse, Context \& Media, 25, 78-87. 
Rocha, A. R. C., \& da Rocha, A. (2013). Observação participante aplicada a pesquisas em marketing sobre turismo e lazer. Caderno Virtual de Turismo, 13(3), 341-353.

Ryabov, I. (2016). Conspicuous consumption among Hispanics: Evidence from the consumer expenditure survey. Research in Social Stratification and Mobility, 44, 68-76.

Santos, F. C., \& Cypriano, C. P. (2014). A internet e as novas dimensões do consumo Francisco Coelho. VII Encontro Nacional de Estudos do Consumo, III Encontro Luso-Brasileiro de Estudos do Consumo, I Encontro Latino-Americano de Estudos do Consumo. Rio de Janeiro, Brasil. Retrieved from http://www. estudosdoconsumo.com.br/artigosdoenec/ENEC2014-GT02 dosSantos Cypriano-Internet_e_as_novas_dimensoes_do_consumo.pdf

Shankar, A., Elliot, R., \& Fitchett, J. A. (2009). Identidy, consumption and narratives of socialization. Marketing Theory, 9(1), 75-94.

Smith, C. (2017, May). By the numbers: 230 + Interesting Instagram Statistics. Retrieved from http://expandedramblings.com/index.php/importantinstagram-stats

Taylor, D. G. (2016). Does Facebook usage lead to conspicuous consumption? The role of envy, narcissism and self-promotion. Journal of Research in Interactive Marketing, 10(3), 231-248.

Thoumrungroje, A. (2014). The influence of social media intensity and EWOM on conspicuous consumption. Procedia-Social and Behavioral Sciences, 148, 7-15.

Trindade, T. O., Ayrosa, E. A. T., \& Sauerbronn, J. F. R. (2015). Consumption and resistance in the context of Brazilian housewives and consumers' movement. Sociedade, Contabilidade e Gestão, 10(3), 105-117.

Vasconcelos, I. F. G. D., \& Vasconcelos, F. C. D. (2001). Identity and change: The past as strategic asset. Organizações \& Sociedade, 8(21), 45-57.

Veblen, T. (1988). A teoria da classe ociosa: Um estudo econômico das instituições. São Paulo: Livraria Pioneira.

Vohra, A. V. (2016). Materialism, impulse buying and conspicuous consumption: A qualitative research. Global Business Review, 17(1), 51-67.

Wang, Y., \& Griskevicius, V. (2014). Conspicuous consumption, relationships, and rivals: Women's luxury products as signals to other women. Journal of Consumer Research, 40(5), 834-854. 


\section{Zanette, M. C., Lourenço, C. E., \& Brito, E. P. Z. (2013). O peso do varejo, o peso no varejo e a identidade: Uma análise de consumidoras plus size. Revista de Administração de Empresas, 53(6), 539-550.}

\section{AUTHOR NOTES}

Bruna L. L. Dantas, master from the Center of Applied Social Sciences (CCSA), Federal University of Paraíba (UFPB); Nelsio R. Abreu, Ph.D from the Department of Management and Economics (DAE), Federal University of Lavras (Ufla).

Bruna L. L. Dantas is now doctorate student at the Center of Applied Social Sciences (CCSA) of UFPB; Nelsio R. Abreu is now professor and researcher at the Department of Management (DA) of UFPB.

Correspondence concerning this article should be addressed to Bruna L. L. Dantas, campus I, Programa de Pós-Graduação em Administração (PPGA), Centro de Ciências Sociais Aplicadas (CCSA), Universidade Federal da Paraíba, Cidade Universitária, João Pessoa, Paraíba, Brazil, CEP 58051-900.

E-mail: brunalimadantas.adm@gmail.com

EDITORIAL BOARD

Editor-in-chief

Gilberto Perez

Associated Editor

Simone Costa Nunes

Technical support

Vitória Batista Santos Silva
EDITORIAL PRODUCTION

Publishing coordination

Jéssica Dametta

Layout designer

Emap

Editorial intern

Paula Di Sessa Vavlis

Graphic designer

Libro
Language editor

Daniel de Almeida Leão 